\title{
Motivational Teaching Strategies and EFL Students' Essay Writing Proficiency
}

\author{
Puspa Dewi, Abdurrachman Faridi, Mursid Saleh and Sri Wuli Fitriati \\ Universitas Negeri Semarang, Indonesia \\ https:// orcid.org/0000-0002-5806-3624 \\ https://orcid.org/0000-0002-6250-9692 \\ https:// orcid.org/0000-0002-4049-5322 \\ https://orcid.org/0000-0002-6405-1371
}

\begin{abstract}
Motivation is considered a complex and challenging issue in teaching, especially in second language courses. Many studies have been conducted about motivational strategies in teaching English language, however, the research that focuses on essay writing is still rare. Therefore, this research aims to describe the effect of the motivational strategies on students' essay writing proficiency and their response to its implementation. These strategies include Creating the Basic Motivational Condition (CBMC), Generating Initial Motivation (GIM), Maintaining and Protecting Motivation (MPM), and Encouraging Positive Retrospective SelfEvaluation (EPRS). The research participants were third-semester undergraduates in a private university, in Indonesia, that enrolled in essay writing. The data were collected by conducting essay writing tests and interviews. The results revealed that there was a statistically significant impact on the students' writing scores, as observed from the improvement from their pre-test to post-test scores In addition, the data from the interview showed the students' positive response and consciousness of their writing progress which indicated the appropriateness of the strategies in their class. The results showed the necessity of implementing motivational strategies as a new model of English instruction by writing lecturers and English teachers in general.
\end{abstract}

Keywords: English as a Foreign Language students; motivational teaching strategies; essay writing proficiency

\section{Introduction}

Motivation is a crucial aspect of achieving one's goals while learning, It is one of the methods of assessing second language (L2) proficiency and maintaining students' enthusiasm for learning (Ruesch et al., 2012). It was stated as the primary factor that influences college students' behaviour (Covington \& Teel, 1999). And it is often described as an internal controller which encourages force, wish, or desire (Deniz in Camit et al., 2014). Furthermore, it is a combination of situational 
and personal influences that prompt people to engage in activities (Alexeeva in Lukianova, 2016). Students' motivation is the most important factor in their language learning quest (McEown \& Takeuchi, 2014). It has an impact on how a learner grasp a second language and it decides whether they succeed or fail (Ditual, 2012). Motivation is important because it defines a learner's persistence in a course, level of engagement, job quality, and success (Hartnett in Panagiotidis et al., 2018). It has an effect on students' desire and need to participate in all learning experiences, as well as their academic achievement (Fairbrother in Ghbari, 2016). Often EFL teachers use motivational techniques in their classrooms to educe inspiration in English language during learning.

At the university level, there are several forms of writing subjects, which include essay writing. An essay is made up of several paragraphs that are all on the same subject and have the same key concept. It usually contain three major sections, namely Introduction, body, and conclusion (Oshima \& Hogue, 1998). It sometimes describe a topic directly or indirectly, in a serious or humorous tone, in order to express personal views. The writer, in the first paragraph outlines the essay's topic, gives meaning to it, presents the general overview, and piques readers' attention. The body of the essay sometimes take one or two paragraphs, because it describes the topic's subdivisions. It is the longest part of the article, and its number in essay writing varies based on the subtopics' structure. The conclusion is the general description or re-examination of the key issues raised in the body. Transition signals are critical for establishing a logical connection between the three sections of an essay (Oshima \& Hogue, 1998). Moreover, there are four categories of essays, namely chronological order, cause and effect, comparison/contrast, and argumentative, depending on the organizational level. A written essay in which a sequence of incidents are described is known as chronological order. The causeand-effect essay, which is normally written in block or chain style, explains why something happened and consequences of those occurrences. In the block concept, the outcomes are discussed and analysed, while all the causes and effects are presented in a sequence, in the chain classification. Similarities and distinctions between two items are explained in the comparison/contrast essay. And argumentative essay deals with thoughts and arguments of a writer on a particular subject (Oshima \& Hogue, 1998). Furthermore, motivation is important in instructing second language and its writing success (Karaca \& Inan, 2020). In order to inspire pupils in the classroom, teachers should use a variety of strategies (Johnson, 2012), and one of these is the motivational approach.

The teacher in this study employed persuasive techniques when teaching four different styles of essays. The strategies were CBMC, GIM, MPM, and EPRS. Motivational strategies (MSs) are instructional techniques used by teachers to increase and sustain students' interest in a subject (McEown \& Takeuchi, 2014). Students grow their confidence in a course and an optimistic expectation of achievement with the aid of these techniques (Keller et al in Ghbari, 2016).

Many countries, including Indonesia, have studied motivational strategies, which showed difference in students' and teachers' expectations of their application (Karaca \& Inan, 2020). Astuti (2013) discovered this gap the Encouraging Positive 
Retrospective Self-Evaluation (EPRS) technique. This method was based on teaching students to assess their own learning in order to increase inspiration. It was also based on educating English teachers on establishing positive relationships with their students and choosing suitable teaching materials. While several studies on motivational strategies have been undertaken in different countries, the study which has directly investigated its effect on students' essay writing proficiency in Indonesian universities is still rare. Therefore, it became necessary to study this field as one of the factors lecturers need to consider when implementing motivational techniques as a new model of English instruction.

\section{Literature Review}

Techniques that help language learners to accomplish their goals are referred to as motivational methods (Dörnyei in Sugita \& Takeuchi, 2010; Wong, 2014). And this strategy as proposed by Dörnyei in 2001, has become the primary concern of EFL practitioners and researchers. Due to various culture-specific reasons, such as repeated tests, broad class sizes, cultural expectations, and an overemphasis on students' obedience, L2 teachers overlook certain crucial techniques. (Cheng \& Dörnyei in Lee et al., 2019). One of these, is the motivational strategy (MS) which has four components, namely CBMC, GIM, MPM, and EPRS (Dörnyei, 2001). During these four steps, students' confidence is planned, created, promoted, sustained, and safeguarded. They are broken down into 35 techniques and three teaching steps, I.e., pre-teaching, in-class, and after-class teaching.

In the pre-teaching step, CBMC and GIM are practiced. The first motivational strategy is important because it serves as an effective mood-booster for students to join the class. It is established from the moment the lecturer demonstrates enthusiasm for teaching, creating a welcoming and motivating environment. Some strategies invoked in the GIM category are as follows, inviting peer-role model, increasing the students' ability to produce essay, and making the curriculum relevant to the students' need. During the in-class teaching step, MPM category with fourteen strategies is practiced by the lecturer. The strategies at this actional phase are performed to reduce any distractions which results in demotivation. From the fourteen strategies, the lecturer pick those that are applicable. And at the after-class step, the lecturer encourages positive selfevaluation. The students' feeling toward their accomplishment and the level of their satisfaction after completing the task influence the lecturer's method of approach. By implementing appropriate strategies, the learners are able to evaluate themselves of the progress of their learning.

According to Dörnyei (2001), there are four components and thirty five subcomponents of MS. They are as follows.

a. $\mathrm{CBMC}$

1) Demonstrating and discussing the lecturer's enthusiasm for the subject of Essay Writing and its value to students

2) Caring about the students' efforts in writing their essays

3) Building a personal contact with the students in the classroom, both during and after lecture

4) Establishing a cooperative connection with the parents of the students 
5) Creating a welcoming and encouraging environment in the classroom.

6) Encouraging the growth of group cohesion.

7) Formulating clear group norms that are effective during essay Writing tasks and assignments, and having the learners discuss and accept them.

8) Consistently observing group norms

b. GIM

1) Presenting peer role models in writing activities, to promote the learners' language-related values.

2) Increasing the inherent interest of students in the learning process.

3) Promoting an optimistic and receptive outlook toward English, particularly in writing, to encourage 'integrative' ideals.

4) Raising students' understanding of the instrumental values that are associated with writing skill knowledge.

5) Increasing students' confidence in their ability to succeed in specific tasks during writing class and learning in general.

6) Increasing pupils' goal-orientedness by establishing concrete class goals that they embrace.

7) Making the Essay Writing curriculum and instructional materials available to students.

8) Assisting learners in developing accurate perceptions about their writing abilities.

c. MPM

1) Breaking up the monotony of classroom activities in order to make essay writing lesson more engaging and entertaining.

2) Increasing the attractiveness of the writing activities in the class to make it more exciting and entertaining.

3) Enlisting students to participate in active tasks to make workshop more engaging.

4) Using motivational methods to present and administrate writing assignments.

5) During essay writing workshop, goal-setting techniques should be utilized.

6) Using contractual strategies with students in Essay writing class to encourage their objective commitment.

7) Providing students with regular examples of professional' writing success.

8) Increasing learners' confidence by encouraging them to learn to write on a regular basis.

9) Assisting in the reduction of language anxiety, by removing or reducing anxiety-provoking aspects.

10) Instilling confidence in the learners' writing talents through the instruction of numerous learner tactics.

11) Enabling students to retain a favorable social image while working on assignments.

12) Increasing student enthusiasm in writing class by encouraging collaboration among them. 
13) Increasing student enthusiasm in writing class by actively supporting learner autonomy.

14) Improving pupils' ability to self-motivate in their writing skills.

\section{d. EPRS}

1) Encouraging students to attribute effort to their writing abilities.

2) Providing positive comments to students on writing activities and assignments.

3) Increasing learners' happiness in Essay writing class.

4) Offering encouraging prizes for pupils' writing accomplishments.

5) Offering rewards for participating in activities, to allow students become interested. This is because they require creative goal-oriented behaviours, which assess students' writing achievement in a motivational method, and minimizing the demotivating effect of grades (Dörnyei, 2001, p. 29)

Motivational strategy has been researched and discovered to produce useful information on the benefits of language teaching. Harmer (2001) stated that teachers of languages have reported that students that really want to learn succeed no matter their circumstance. All the teachers recounted situations in which certain "motivated" students did significantly better than their peers. This led to the conclusion that students frequently succeed in what appear to be unfavorable conditions, even when treated with methods which experts consider unsatisfactory. This phenomenon suggests that the motivation the students bring to class is the biggest single factor which affect their success (Bahous, 2011; Dembo, 2004; Kakar \& Pathan, 2017).

In addition, Dörnyei in Kakar \& Pathan (2017: 117) stated that motivational strategies are techniques that encourage individuals to promote their behaviors, using different methods. Furthermore, motivational strategy are defined as instructional interventions that are consciously applied by L2 teachers to promote, improve, and maintain students' good behavior. An EFL instructor revealed that to motivate learners, they employed the self-sufficiency motivational strategy. In which they discovered that it promotes learners' autonomy, this has since being very influential in their learning procedure. Moreover, the findings of the study illustrated that teachers strongly supported learners' independence and it resulted in their autonomy. Also,it stated that learner with high autonomy were able to increase their level of understanding to achieve the assigned task by their instructors, which familiarized the teachers with the advantages of L2 learning (Abdullah et al., 2019). It had been researched by many countries, including Indonesia, that there is a gap in the perception of students and teachers regarding the implementation of these techniques (Karaca \& Inan, 2020). Motivational strategies are defined as instructional interventions consciously applied by L2 teachers to elicit, enhance, and sustain student motivated behavior, till graduation, therefore reducing potential distraction (Guilloteaux, 2013).

Writing is a central feature in language learning, which involve grammatical constructions and vocabulary (Cole \& Feng, 2015). For L2 learners, writing is the most difficult task to master (Crookes \& Schmidt, 1991), because it necessitates the use of thought mechanisms in order to deliver successful concepts (Franscy et al., 
2019). When students want to communicate an idea to a reader for a specific reason, writing plays an important role in that. The learner explain things, and as a result, readers gain information by reading the messages (Ratnah, 2018). In order to write a successful composition, students are to include all linguistic components (Nazri et al., 2018). Arrangement, preparation, conceptualization, composition, rewriting, and adjustments are all common requirements for writing (Vijayavalsalan, 2016). Students are to write grammatically correct sentences and link them in a readable and well-formed text (Heaton in Limbong, 2018).

Based on the background of the study, the research questions of this current study are as follows,

(1) What is the effect of implementing motivational teaching strategies on EFL students' essay writing proficiency?

(2) What is the students' response to the implementation of motivational teaching strategies in essay writing class?

\section{Methodology}

A combination of quantitative and qualitative research was utilized in this study. The pre-experimental study was carried out using the quantitative research, while a case study was utilized for that of the qualitative. In the quantitative method, the research issue was determined based on patterns on the field or the need to justify an occurrence. Defining a pattern means that a study addresses the research problem by determining the general disposition of individual responses and noting their differences (Creswell, 2012). In this study, the effect of the implementation of motivational strategies on the students' essay writing proficiency was investigated. And for the qualitative data, interview was conducted to support the findings of the quantitative.

The research sample consisted of twenty-seven students that were enrolled in the only regular essay writing class. They displayed their willingness to participate in the research by the submission of the research consent form. The saturated sampling method was utilized since there was only one class, just as in Sugiyono (2013). Rukminingsih et al. (2020) described saturated sampling as a technique in which all members of the population are utilized. Generalizations were made with as little mistakes as possible since the sample included in this study was comparatively small (less than 30 people).

Arikunto (2015) explained that when the population is less than 100 individuals, the complete sample should be taken. And when it is more than 100,10-15\% or $20-25 \%$ of the population should be utilized as samples. In the previous term, the students had taken sentence and paragraph writing course. Lastly, the study was carried out at a private university in Indonesia's Central Java.

The writing output was restricted to the essay writing course taught in the third semester, where assessments were conducted to determine the students' writing skills. During grading there are three types of scoring, namely, holistic, traitbased, and analytic. An analytical scoring approach was suitable for this study because it was necessary to calculate the five elements of writing, i.e., text, 
organization, grammar, vocabulary, and mechanics. By extracting and measuring individual components, this approach precisely specified the features to be quantified. This method of scoring is more accurate at distinguishing between the weaker texts. Material, organization, and grammar have their own scales in analytic scoring rubrics, where those of vocabulary and mechanics are often added separately. Each of these elements had a numerical value assigned to it (Hyland, 2003), also Brown's scoring method was taken into consideration (Brown, 2007). The participants were required to write essays that followed a certain structure (cause and effect, comparison/contrast, and chronological order) while utilizing proper writing conventions. For their writing to be considered a good composition, they are to consider the appropriate use of grammar, vocabulary, mechanics, content, and organization.

Meanwhile the ten interview items utilized were adapted from Dörnyei (2001) with some modifications, to obtain deeper information about the lecturer's motivational strategies on the students. These strategies included creating the basic motivational condition, generating initial encouragement, maintaining and protecting motivation, and encouraging positive retrospective self-evaluation on their writing progress. The progress of their essays were observed from the five elements of writing, i.e. content, organization, grammar, vocabulary, and mechanics.

The data were collected in sixteen meetings. The first meeting was the pre-test, where the students were assigned to write a chronological essay within 100 minutes. They were offered to choose from the following topics, How to get a driver's license, How to break a bad habit and How to cook a special dish from your culture. The second until the fourteenth meeting were the implementation of motivational strategies. In the fifteenth meeting, an interview was conducted to determine the students' perception on the implementation of motivational strategies by the lecturer during the semester. And the sixteenth meeting was the post-test on writing, where the lecturer offered some topics under cause and effect, comparison/contrast, chronological order, and argumentative organization essay.

Two types of data analysis was utilized in this study, i.e., quantitative and qualitative. The quantitative method, the descriptive analysis was employed to measure the mean and the standard deviation of writing score. In addition, qualitative analysis was conducted to measure the effect of motivational strategies on the students' essay writing proficiency. The data were collected from the results of the essay writing post-test, then they were analyzed using SPSS 22 statistics analysis program. For the qualitative data, the learners' statements from interview were transcribed and coded using thematic analysis.

\section{Research Results}

Writing assessments were used to monitor the development of the students' writing abilities. Students were given the option of writing an essay in chronological order, cause/effect, or comparison/contrast format. 
The pre-test was performed before the implementation of motivational strategies in the essay writing class. The participants were assigned to write a chronological order essay which consisted of 450-500 words. The lecturer offered three topics to choose from, (a) How to get a driver's license, (b) How to break a bad habit, (c) How to cook a special dish from your culture. The consideration for choosing those topics was because the students had background knowledge on them. Their chronological order essays were supposed to cover introductory, three body paragraphs, and one concluding section. Based on the results, it was inferred that the highest score was 77.4, while the lowest was 58.6, and the mean was 65.6. This means that the students' writing performance was in fair category between 65-69. The frequency distribution of the pre-test score is presented in figure 1.

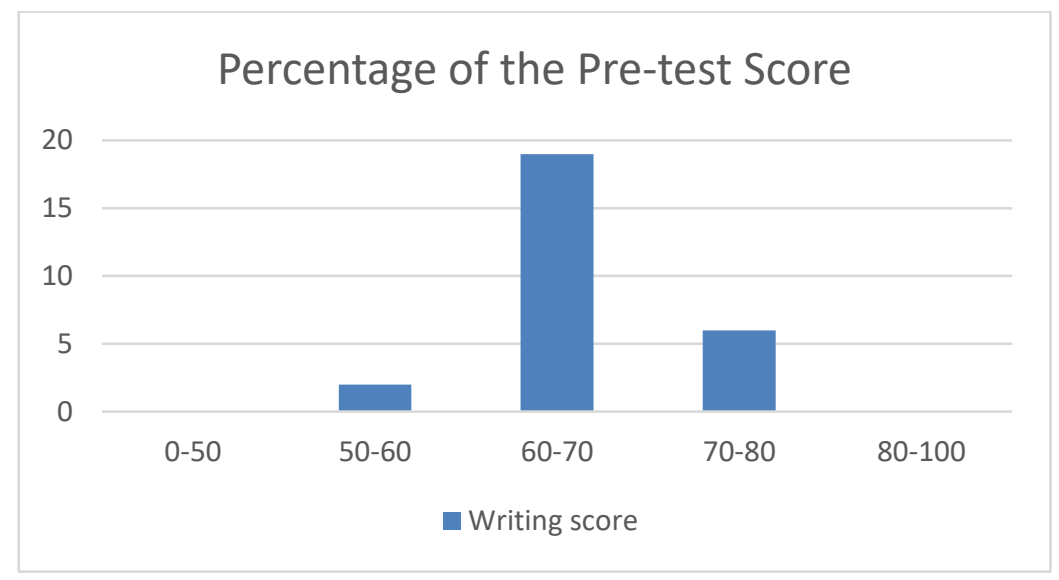

Figure 1. The Frequency Distribution of the Students' Post-test Score

Figure 1 shows that out of 27 students, 6 or $22 \%$ belonged to the good category, 19 or $70 \%$ were in fair category, and 2 or $7 \%$ belonged to the poor classification. There was no students in the excellent category.

The post-test was conducted after the implementation of the motivational strategies with encouraging positive self-retrospective evaluation component. The participants were encouraged to choose one of the patterns of essay organization which consisted of 450-500 words. The lecturer instructed the students to choose their own topic from the following "How to make or prepare traditional foods from Indonesia" (cause and effect), "opening modern market in small town (comparison and contrast), "online free-learning tutorial for students" (chronological order). The consideration was that when they choose their own topic, they enjoy writing and developing their ideas freely based on knowledge and preferences. Their essay should cover introductory, body and one concluding paragraph. It was inferred from the post-test results that the highest score was 88.6 , and the lowest was 71 . The frequency distribution of the post-test score was presented in figure 2 . 


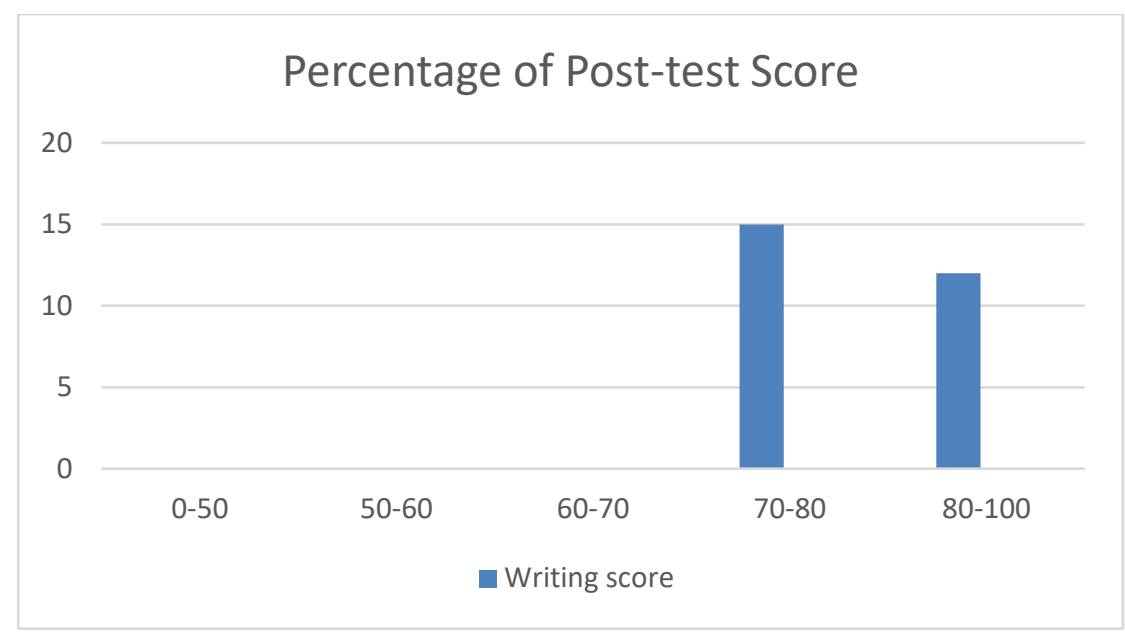

Figure 2. The Frequency Distribution of the Students' Post-test Score

Based on the finding presented in figure 2, it was inferred that the highest score was 88.6, and the lowest was 71 , while the mean was 80.8 . There was an improvement (15.25) of the means' score from pre-test (65.63) to post-test (80.88). Also, figure 2 shows that there were students in the excellent category between $80-100$. Out of 27 students, 15 or $55.5 \%$ belonged to good category, and 12 or $44 \%$ were in the excellent category. Meanwhile, no student belonged to poor and fair classification.

In addition, data were inputted into Microsoft Excel, then the descriptive statistics was conducted using SPSS as presented in table 1.

Table 1: Descriptive Statistics

\begin{tabular}{|c|c|c|c|c|c|c|c|c|}
\hline & \multirow{2}{*}{ 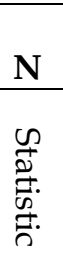 } & \multirow{2}{*}{ 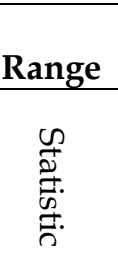 } & \multirow{2}{*}{ 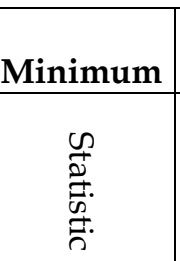 } & \multirow{2}{*}{ 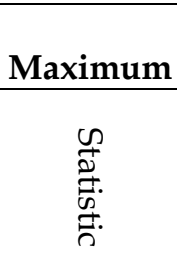 } & \multirow{2}{*}{ 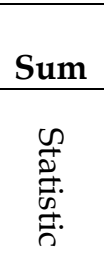 } & \multicolumn{2}{|c|}{ Mean } & \multirow{2}{*}{ 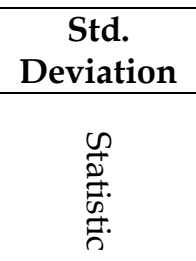 } \\
\hline & & & & & & 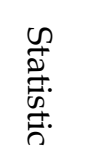 & $\begin{array}{l}0 \\
0 \\
0 \\
5 \\
0 \\
0 \\
0\end{array}$ & \\
\hline pre-test & 27 & 19 & 59 & 77 & 1772 & 65.63 & .993 & 5.159 \\
\hline post-test & 27 & 17 & 72 & 89 & 2184 & 80.88 & 1.076 & 5.590 \\
\hline $\begin{array}{l}\text { Valid N } \\
\text { (listwise) }\end{array}$ & 27 & & & & & & & \\
\hline
\end{tabular}

Table 1 shows that both the computation using Microsoft Excel and SPSS had the same results of the students' writing achievement in the pre-test. The standard deviation of pre-test was 5.16 and that of the post-test was 5.59.

To reveal the normality of the data of pre-test and post-test, its test was carried out. The results are presented in table 2 as follows. 
Table 2: Test of Normality

\begin{tabular}{|l|l|r|}
\hline \multicolumn{2}{|c|}{ One-Sample Kolmogorov-Smirnov Test } \\
\hline \multicolumn{2}{|c|}{} & $\begin{array}{c}\text { Unstandardized } \\
\text { Residual }\end{array}$ \\
\hline $\mathrm{N}$ & Mean & .0000000 \\
\cline { 2 - 3 } Normal Parameters ${ }^{\mathrm{a}, \mathrm{b}}$ & Std. Deviation & 4.45101142 \\
\hline \multirow{2}{*}{ Most Extreme Differences } & Absolute & .122 \\
\cline { 2 - 3 } & Positive & .122 \\
\cline { 2 - 3 } & Negative & -.082 \\
\hline Test Statistic & .122 \\
\hline Asymp. Sig. (2-tailed) & $.200^{c, d}$ \\
\hline
\end{tabular}

a. Test distribution is Normal. c. Lilliefors Significance Correction.

b. Calculated from data. $\quad d$. This is a lower bound of the true significance.

Table 2 shows the normality test results of students' writing score in pre-test and post-test. The Sig. value of the writing score was higher than the level of significance $0.05(0.200>0.05)$. It was clear that writing score variable was in normal distribution. In addition, to reveal the effect of the implementation of motivational strategies to the students' essay writing score, Paired Samples test was administered. This test belongs to a parametric statistical test. The goal of the test is to determine whether the results of pre-test and post-test are statistically different.

Table 3: Paired Samples Test

\begin{tabular}{|c|c|c|c|c|c|c|c|c|}
\hline & \multicolumn{5}{|c|}{ Paired Differences } & $\mathrm{t}$ & $\mathrm{df}$ & $\begin{array}{l}\text { Sig. (2- } \\
\text { tailed) }\end{array}$ \\
\hline & \multirow[b]{2}{*}{ Mean } & \multirow{2}{*}{$\begin{array}{c}\text { Std. } \\
\text { Deviation }\end{array}$} & \multirow{2}{*}{$\begin{array}{l}\text { Std. } \\
\text { Error } \\
\text { Mean }\end{array}$} & \multicolumn{2}{|c|}{$\begin{array}{c}95 \% \text { Confidence } \\
\text { Interval of the } \\
\text { Difference }\end{array}$} & & & \\
\hline & & & & Lower & Upper & & & \\
\hline $\begin{array}{r}\text { Pair } 1 \text { pre-test - } \\
\text { post-test }\end{array}$ & -15.252 & 5.358 & 1.031 & -17.371 & -13.132 & -14.792 & 26 & .000 \\
\hline
\end{tabular}

Based on table 3, the value of negative rank was 0 and that of the positive was 27 which meant the results of post-test was higher than that of pre-test. The average rank of pre-test and post-test was 14.792. In addition, the results of Asymp. Sig. (2-tailed) 0.000 was lower than 0.005 which meant that the alternative hypothesis was accepted that there was significant effect of the implementation of motivational strategies on the students' writing proficiency.

Furthermore, the improvement of the students' writing proficiency was observed from each writing elements, i.e., text, organization, grammar, vocabulary, and mechanics. The mean of text improved from 63.8 to 80.9 (17.1), that of organization improved from 66 to 82.1 (18.5), grammar from 66.2 to 79.6 (13.4), vocabulary from 67.5 to 80.4 (12.9); and that of mechanics improved from 66.9 to 81.3 (14.3). The highest improvement was at organization. This indicates that the students' essay were constructed well. 
To support the quantitative findings, interview with students was carried out to get deeper information on whether motivational strategies helped the students to improve their writing proficiency. The results of the interview are presented as follows.

Table 4: The Students' Response on Motivational Strategies to Improve Their Writing

\begin{tabular}{|c|c|c|}
\hline $\begin{array}{l}\text { Interview } \\
\text { Items }\end{array}$ & Coding results & Example of statements \\
\hline $\begin{array}{l}\text { Creating the } \\
\text { basic } \\
\text { motivational } \\
\text { conditions }\end{array}$ & $\begin{array}{l}\text { Preparing the } \\
\text { Students both } \\
\text { physically and } \\
\text { mentally ready } \\
\text { for writing class } \\
\end{array}$ & $\begin{array}{l}\text { "I became more ready to join the essay writing class } \\
\text { than before because the lecturer gave us motivation } \\
\text { in the beginning." } \\
\text { "I come to class on time than before." }\end{array}$ \\
\hline $\begin{array}{l}\text { Generating } \\
\text { initial } \\
\text { motivation }\end{array}$ & $\begin{array}{l}\text { Generating } \\
\text { positive students } \\
\text { attitude towards } \\
\text { learning }\end{array}$ & $\begin{array}{l}\text { "I like learning when one of my intelligent } \\
\text { classmates help me to understand the material." } \\
\text { "The lecturer negotiate the learning goals in } \\
\text { writing class. Where I measure my own learning." }\end{array}$ \\
\hline $\begin{array}{l}\text { Maintaining } \\
\text { and } \\
\text { protecting } \\
\text { motivation }\end{array}$ & $\begin{array}{l}\text { Making students } \\
\text { motivated during } \\
\text { learning process }\end{array}$ & $\begin{array}{l}\text { "I like when my lecturer say something funny. I am } \\
\text { able to forget my difficulty for a moment." } \\
\text { "The assignments vary, therefore I learn faster." }\end{array}$ \\
\hline $\begin{array}{l}\text { Encouraging } \\
\text { positive self- } \\
\text { evaluation }\end{array}$ & $\begin{array}{l}\text { Helping students } \\
\text { to consider their } \\
\text { writing } \\
\text { achievement in a } \\
\text { more positive } \\
\text { light }\end{array}$ & $\begin{array}{l}\text { "I feel happy whenever I make improvement from } \\
\text { each task. My lecturer shows me these areas." } \\
\text { "I feel satisfied when my lecturer gives me score } \\
\text { for my achievement." }\end{array}$ \\
\hline Content & $\begin{array}{l}\text { Improving topic } \\
\text { and details }\end{array}$ & $\begin{array}{l}\text { "Motivational strategies help me to improve my } \\
\text { ideas in writing." } \\
\text { "I am able to explore my ideas and arrange them } \\
\text { in good composition of writing." }\end{array}$ \\
\hline Organization & $\begin{array}{l}\text { Improving } \\
\text { identification and } \\
\text { description }\end{array}$ & $\begin{array}{l}\text { "Motivational strategies improve the organization } \\
\text { of my essay." } \\
\text { "Motivational strategies make my essay more } \\
\text { structured." }\end{array}$ \\
\hline Grammar & $\begin{array}{l}\text { Improving correct } \\
\text { tense and } \\
\text { agreement }\end{array}$ & $\begin{array}{l}\text { "Motivational strategies enable students to } \\
\text { understand the rules of writing an essay." } \\
\text { "Motivational strategies allow me to enhance my } \\
\text { grammar competence." }\end{array}$ \\
\hline Vocabulary & $\begin{array}{l}\text { Improving word } \\
\text { choice and word } \\
\text { form }\end{array}$ & $\begin{array}{l}\text { "Motivational strategies encourage us to keep } \\
\text { learning till the essay is properly constructed. They } \\
\text { also enable us to acquire new vocabularies." } \\
\text { "Motivational strategies enhance my vocabulary } \\
\text { because I endeavour to learn new concepts." }\end{array}$ \\
\hline Mechanics & $\begin{array}{l}\text { Improving } \\
\text { spelling, } \\
\text { punctuation, and } \\
\text { capitalization }\end{array}$ & $\begin{array}{l}\text { "Motivational strategies produce many benefits, } \\
\text { and one of them is capitalization because } \\
\text { sometimes I forget to use the capital letter." } \\
\text { Motivational strategies improved my ability to use } \\
\text { correct spelling, capitalization, and punctuation." } \\
\text { "Motivational strategies allow me to know the } \\
\text { correct spelling and capitalization." }\end{array}$ \\
\hline
\end{tabular}


Based on these results, the students showed positive responses toward the implementation of MS in their writing class. Each of the four components of MS helped them to prepare to join the writing class, kept their motivation, and have a positive attitude toward learning and achievements. In addition, MS produced positive effects on the content of their essays, it helped the students adjust the goals of writing, explore their ideas, and made their writing clear. Also motivational strategies improved the organization of the essay, where the students' writing became more structured. Moreover, motivational strategies enabled students to know how to write an essay well by writing good composition, although they still needed a guide from the lecturer. Students had a great desire to learn, because they had high motivation. In addition, these techniques improved students' vocabulary, which helped them to explore with words, enabling them write better essays. This technique also prompted them to keep learning, and also enabled students to understand how to write an essay correctly and structurally. It also helped the students to understand the rules of writing an essay, and enhanced their grammar competence. Furthermore, this technique helped in capitalization and it improved their abilities to use correct spelling and punctuation. Motivational strategies made them enjoy writing because it became fascinating. Finally, the students had great understanding of how to write an essay appropriately, especially in using correct spelling and punctuation.

\section{Discussion}

According to the results, students' writing success increased after the motivational strategies were applied. The increment of the mean score from pre-test to posttest showed that with the sufficient implementation of MS in writing class particularly in essay, students learn better, and this improvement was observed in all the writing elements. The strategies which were adapted from Dörnyei (2001) where four categories were selected and implemented sufficiently by the lecturer, from considering the students' needs to class conditions. During the fourteen meetings, different topics of writing were selected, students were asked to choose the topics and they were freely developed into essays by them through the guidance and monitoring of the lecturer. Freely developed into an essay meant that the topics were narrowed according to the students' preference. The lecturer believed that this strategy strongly boosted the students' motivation to write on their own. Meanwhile the role of the lecturer during the implementation of the strategies was offering assistance when dealing with writing problems. Their motivation improved the performance, which was evident from the test results. These results is in line with a research conducted by Karimi \& Zade (2018) on the impact of teachers' use of motivational strategies on learners' motivation. It was discovered that the use of this strategy resulted in a substantial increase in learners' motivation, which has a crucial role in teaching and learning process. It also boost the students' effort to obtain better achievement in learning. The results also agreed with Ghbari's study (2016), which showed that the motivational paradigm had a positive impact on tenth-grade students' success drive and academic achievement. And also with Lee et al. (2019) on the impact of teachers' motivational methods on students' learning achievement. Based on students' selfreport via their reflective journals, the use of foreign language motivational 
strategies led to the desirable effects. Also, the study revealed that the more motivated students were, the higher the writing score they achieved, in another words motivation played important role in second language writing.

From the results of the interview with the students, it was reported that there was a significant effect of the implementation of motivational strategies on the learner. There were five writing aspect that were the focus of the improvement, and the students improved in all, i.e., organization, content, grammar, vocabulary, and mechanics. This conforms to the research conducted by Bruning \& Horn (2000) which stated that motivation to write, needs to be initiated by the teachers through building the students' belief about the nature of writing and potential, authentic goals and context, supportive tasks condition, and approaches to deal with the negative effects and establishing new productive ones. In addition, it is in line with Cheng \& Dörnyei (2007) which reported that language teachers that focus on setting a positive example (Teacher), making a solid rapport with students (Rapport), creating a pleasant and relaxed atmosphere in the classroom (Climate), and making sure that students understand the tasks in which they are interested in (Task), significantly contribute to the learners' success in language learning. When teachers are concerned about teaching practices that deal with these macrostrategies, students become more interested in the foreign language classroom (Ruesch et al., 2012). Furthermore, the results of the interview support the findings from Ghanizadeh \& Rostami (2015) which stated that it is important to emphasize the role of forming positive attitudes toward second language learning and in motivating learners to make intentional efforts to learn English.

\section{Conclusion}

Motivational strategies have an important impact on students' abilities to write good essays, according to this research. Students' essay writing scores improved significantly from the pre-test to the post-test, as shown by the results. This study proposed that learning should be developed in three motivational methods, namely (1) setting specific and appropriate objectives as motives for learning, (2) engaging students to become active learners, and (3) creating and sustaining a positive learning environment. This is because motivated students are more likely to participate in the learning process than others. Furthermore, the results of this study provide insights to English teachers in Indonesia to increase their students' achievement through motivational strategies. In addition, it is highly recommended for the policymakers to provide trainings, where educators are trained to teach students using these techniques. Other variables, such as conditions affecting the success of second language learning and motivating attribution by teachers and learners, require further investigation.

\section{Acknowledgements}

This research received no specific grant from any funding agency in the public, commercial, or not-for profit sectors.

\section{References}

Abdullah, M. Y., Ghafri, H. M. H. A., \& Yahyai, K. S. H. A. (2019). A qualitative study on the best motivational teaching strategies in the context of Oman: perspectives of 
EFL teachers. English Language Teaching, 12(3), 57-64. https://doi.org/10.5539/elt.v12n3p57

Arikunto, S. (2015). Prosedur penelitian: suatu pendekatan praktik [Research procedure: a practical approach]. Rineka Cipta. Bandung.

Astuti, S. P. (2013). Teachers' and students' perceptions of motivational teaching strategies in an Indonesian high school context. TEFLIN Journal, 24(1), 14-31.

Bahous, R. (2011). Motivating students in the EFL classroom: a case study of perspectives motivating students in the EFL classroom: a case study of perspectives. August. https:// doi.org/10.5539/elt.v4n3p33

Bruning, R., \& Horn, C. (2000). Developing motivation to write. Educational Psychologist, 35(1), 25-37. https://doi.org/10.1207/S15326985EP3501_4

Camit, A., Artista, L., Javelosa, S., \& LaTorre, J. (2014). The moderating effects of metacognition to the relationship between goal orientation and student motivation in the digital generation. Asian EFL Journal, 79, 61-87.

Cheng, H.-F., \& Dörnyei, Z. (2007). The use of motivational strategies in language instruction: the case of EFL eaching in taiwan. Innovation in Language Learning and Teaching, 1(1), 153-174. https:/ / doi.org/10.2167/illt048.0

Cole, J., \& Feng, J. (2015). Effective strategies for improving writing skills of elementary English language learners. Chinese American Educational Research and Development Association Annual Conference, 1-25.

Covington, M. V., \& Teel, K. M. (1999). Overcoming student failure: changing motives and incentives for learning. American Psychological Association.

Creswell, J. W. (2012). Educational research: planning, conducting, and evaluating quantitative and qualitative research (Fourth Edition). Pearson Education, Inc.

Crookes, G., \& Schmidt, R. W. (1991). Motivation: reopening the research agenda. Language Learning, 41(4), 469-512.

Ditual, R. C. (2012). The motivation for and attitude towards learning English. Asian EFL Journal Press, 63, 1-12.

Dörnyei, Z. (2001). Motivational strategies in the language classroom. Cambridge University Press.

http:/ / public.ebookcentral.proquest.com/choice/publicfullrecord.aspx?p=4636 589

Franscy, Sunendar, D., \& Rahmat, A. (2019). The effectiveness of contextual teaching and learning approach on the students' argumentative writing skills. Asian EFL Journal, 25(5.1), 32-42.

Ghanizadeh, A., \& Rostami, S. (2015). A Dörnyei-inspired study on second language motivation: a cross-comparison analysis in public and private contexts. Psychol Stud, 60(3), 292-301. https:/ / doi.org/10.1007/s12646-015-0328-4

Ghbari, T. A. (2016). The effect of ARCS motivational model on achievement motivation and academic achievement of the tenth grade students. The New Educational Review, 43(1), 68-77. https:/ / doi.org/10.15804/tner.2016.43.1.05

Guilloteaux, M.-J. (2013). Motivational strategies for the language classroom: Perceptions of Korean secondary school English teachers. ScienceDirect, 1-12. http:/ / dx.doi.org/10.1016/j.system.2012.12.002

Harmer, J. (2001). How to teach English. Pearson Education Limited. Malaysia.

Johnson, M. P. (2012). Examining EFL motivation in Japanese engineering students. The Asian ESP Journal, 8(2), 79-102.

Kakar, S. K., \& Pathan, Z. H. (2017). Exploring the motivational strategies practiced by Pakistani EFL teachers to motivate students in learning English language. 7(2), 117-123. https://doi.org/10.5539/ijel.v7n2p117 
Kalmari, I. (2017). Motivational strategies used by English teachers: Students ' opinions (Bachelor' s thesis. University of Jyväskylä).

Karaca, M., \& Inan, S. (2020). A measure of possible sources of demotivation in L2 writing: A scale development and validation study. ELSEVIER, 43, 1-15. https://doi.org/10.1016/j.asw.2019.100438

Karimi, M. N., \& Zade, S. S. H. (2018). Teachers' use of motivational strategies: Effects of a motivation-oriented professional development course. Innovation in Language Learning and Teaching, 1-11. https:/ / doi.org/10.1080/17501229.2017.1422255

Lee, T. S. O., Gardner, D., \& Lau, K. (2019). The effects of L2 motivational strategies: Within and beyond the L2 classroom. Innovation in Language Learning and Teaching, 1-15. https://doi.org/10.1080/17501229.2019.1620240

Limbong, S. (2018). The influence of lecturer's pedagogic and professional competences on students' writing proficiency at maritime education and training. Asian ESP Journal, 14(1), 342-358.

Lukianova, L. (2016). Motivation factors of adult learning. The New Educational Review, 44(2), 223-229. https://doi.org/10.15804/tner.2016.44.2.18

McEown, M. S., \& Takeuchi, O. (2014). Motivational strategies in EFL classrooms: How do teachers impact students' motivation? Innovation in Language Learning and Teaching, 8(1), 20-38. https://doi.org/10.1080/17501229.2012.741133

Nazri, N. M., Yunus, M. M., \& Shukor, D. M. A. (2018). The Effectiveness of using mindomo as a pre-writing tool in improving writing scores among ESL students. Asian ESP Journal, 14(5), 64-74.

Oshima, A., \& Hogue, A. (1998). Writing academic English. Addison Wesley Longman.

Panagiotidis, P., Krystalli, P., \& Arvanitis, P. (2018). Technology as a motivational factor in foreign language learning. European Journal of Education, 1(3), 43-52.

Ratnah. (2018). Improving writing skills by using authentic materials in Indonesian vocational school. Asian EFL Journal, 20(7), 124-129.

Ruesch, A., Bown, J., \& Dewey, D. P. (2012). Student and teacher perceptions of motivational strategies in the foreign language classroom. Innovation in Language Learning and Teaching, 6(1), 15-27. http:/ / dx.doi.org/10.1080/17501229.2011.562510

Rukminingsih, Wardhono, A., \& Rohmawati, P. (2020). Metode praktis penelitian pendidikan (practical methods of educational research). Erhaka Utama.Yogyakarta.

Sugita, M., \& Takeuchi, O. (2010). What can teachers do to motivate their students? A classroom research on motivational strategy use in the Japanese EFL context. Innovation in Language Learning and Teaching, 4(1), 21-35. https:/ / doi.org/10.1080/17501220802450470

Sugiyono. (2013). Metode penelitian pendidikan: pendidikan kualitatif, kuantitatif, dan $R \mathcal{E} D$ (Educational research methodology: qualitative, quantitative, and RED). Alfabeta.

Vijayavalsalan, B. (2016). Mind mapping as a strategy for enhancing essay writing skills. The New Educational Review, 137-150. https:// doi.org/10.15804/tner.2016.45.3.11

Wong, R. M. H. (2014). An investigation of strategies for student motivation in the Chinese EFL context. Innovation in Language Learning and Teaching, 8(2), 132-154. https://doi.org/10.1080/17501229.2013.777449 